Original Article

\title{
Attenuation of core temperature elevation and interleukin-6 excretion during head-out hot water immersion in elderly people
}

Mami Yamashiro, RPT ${ }^{1)}$, Yukinide Nishimura, $\mathrm{MD}, \mathrm{PhD}^{2}$, Yukio Mikami, MD, $\mathrm{PhD}^{1 \text { )* }}$, Ken Kouda, MD, PhD ${ }^{1)}$, Yuta Sakurai, RPT ${ }^{3)}$, Izumi Yoshioka, MD ${ }^{3)}$, Tokio Kinoshita, RPT ${ }^{1)}$, Daisuke Kojima, RPT ${ }^{1)}$, Fuminiro Tajima, MD, PhD ${ }^{1)}$

1) Department of Rehabilitation Medicine, Wakayama Medical University: 811-1 Kimiidera, Wakayama 641-8509, Japan

2) Department of Rehabilitation Medicine, Iwate Medical University, Japan

3) Research Center of Sports Medicine and Balneology, Wakayama Medical University, Japan

\begin{abstract}
Purpose] Previous studies have demonstrated a link between core body temperature and interleukin-6 production. Recent studies have reported that 20 minutes of head-out immersion in hot water $\left(42^{\circ} \mathrm{C}\right)$ increased serum interleukin-6 levels in young males. This study aimed to compare the efficacy of head-out immersion in hot water $\left(42^{\circ} \mathrm{C}\right)$ on serum interleukin-6 levels in seven elderly (66-75 years old) and eight young males (21-32 years old). [Participants and Methods] Venous blood samples were drawn at rest, immediately after head-out immersion in hot water $\left(42^{\circ} \mathrm{C}\right)$, after 1 hour, and after 2 hours. Levels of serum interleukin- 6 , tumor necrosis factor- $\alpha$, and high-sensitivity C-reactive protein; blood cell counts; and core temperature were measured. [Results] It was found that 20 minutes of head-out immersion in hot water $\left(42^{\circ} \mathrm{C}\right)$ increased the core temperature in both the elderly and young participants; however, the rise in core temperature was more attenuated in elderly participants. Serum interleukin-6 levels were significantly higher in young participants 1 hour after the head-out immersion in hot water $\left(42^{\circ} \mathrm{C}\right)$; however, serum interleukin- 6 levels did not change in elderly participants. Serum tumor necrosis factor- $\alpha$ and high-sensitivity C-reactive protein levels remained constant throughout the study the elderly and young participants. [Conclusion] The current study demonstrated that head-out immersion in hot water $\left(42^{\circ} \mathrm{C}\right)$ more attenuated core temperature and interleukin-6 levels in elderly participants than in young participants. We assert that these differences are likely to be related to age-related changes in core temperature regulation and muscle fibers.

Key words: IL-6, Hyperthermia, Core temperature
\end{abstract}

(This article was submitted Feb. 14, 2020, and was accepted Apr. 14, 2020)

\section{INTRODUCTION}

The aging process induces to reduce physical fitness, and results in difficulties in daily life activities. If elderly persons do not take part in physical exercise, they expose themselves to risk of having their muscle mass, endurance and joint motion reduced. In addition to its function in health and disease, interleukin (IL)-6 produced and secreted by skeletal muscles has various beneficial effects on metabolism, such as augmentation of lipolysis, and improvement of insulin sensitivity ${ }^{1-5)}$. Exercise induces increased circulating levels of IL- $6^{6}$, and may be involved in mediating the beneficial health ${ }^{7}$. However, physical inactivity with aging decreases the ability to exercise ${ }^{8)}$.

Previous studies have demonstrated certain interactions between core body temperature (Tcore) and IL-6 production $\left.{ }^{9}, 10\right)$.

*Corresponding author. Yukio Mikami (E-mail: ymikami@outlook.co)

(C2020 The Society of Physical Therapy Science. Published by IPEC Inc.

(c) (1) $\odot$ This is an open-access article distributed under the terms of the Creative Commons Attribution Non-Commercial No Derivatives cc) ${ }_{\text {BY NC ND }}$ (by-nc-nd) License. (CC-BY-NC-ND 4.0: https://creativecommons.org/licenses/by-nc-nd/4.0/) 
Others have reported that a small difference in rectal temperature (equal to $0.4^{\circ} \mathrm{C}$ ) between exercise under low versus high air velocity conditions was associated with 3- to 4-fold lower absolute change in serum IL-6 levels from high to low conditions ${ }^{11)}$. Sakurai et al. ${ }^{12)}$ found an increase in serum IL-6 level during heat stress in young individuals, using the hot water immersion method. Regarding IL-6 elevation during exercise and heat stress, both IL-6 are secreted from muscle cells, however the mechanism of IL-6 production is different. It has been reported that IL- 6 is produced by activation of mitogenactivated protein kinase during exercise, however IL-6 is produced by heat shock factor during heat stress ${ }^{13}$, 14). Head-out water immersion (HOI) in hot water (hot-HOI) is a well-known heat stress method. To our knowledge, however, there are no studies that measured changes in Tcore and serum IL-6 in elderly persons during hot-HOI.

Elderly individuals are at greater risk of developing life-threatening manifestations of heat stress, such as heat stroke, than young individuals ${ }^{15}$. In hot water immersion, the lack of heat-based vaporization can limit aging-related changes in thermoregulatory function. Consequently, hot-HOI may induce hyperthermia in elderly men that is equal to that in young persons.

Exercise increases serum IL-6 levels in healthy young men and elderly men, however, the increase of IL-6 response is less pronounced in the elderly compared with young individuals ${ }^{16)}$. It's of concern that reduced physical activity in elderly people negatively affects their exercise induced IL-6 excretion. If hot-HOI can increase circulatory IL-6 to levels that are equivalent to those seen during exercise, examination of the effect of hot water immersion on age-related serum IL-6 level is interesting in physical therapy of the elderly.

The present study was designed to compare the effects of hot-HOI on changes in Tcore and serum IL-6 levels between young and elderly individuals.

\section{PARTICIPANTS AND METHODS}

Seven healthy elderly (66-75 years old) males and eight healthy young males (21-32 years old) without underlying disease participated in this investigation. Table 1 lists the characteristics of the study participants. Exclusion criteria are those who have an underlying condition such as diabetes, heart disease, chronic inflammatory disease, or skin disease and none of the study participants were on any medications. The study protocol was approved by the Human Research Ethical Committee of Wakayama Medical University (No.1355) and informed consent was obtained from each participant.

The participants were instructed to refrain from strenuous physical exercise and alcohol the day before the study and to refrain from taking any fluid or food after 22:00 the day before the study except for tap water, until the completion of the study. They reported to the laboratory at 8:00 on the study day. The participants wore swimming trunks. They were asked to void and then sit in a room outside the immersion tank for a 30-min control period. A copper-constantan thermocouple was inserted through the nostril and its tip was advanced to the mid-esophagus to measure Tcore throughout the study. A heparinized indwelling catheter was placed into the right antecubital vein. After confirmation of stable Tcore, the above parameters were measured over a 30-min rest period in the sitting position in air (as pre-HOI or baseline). The participant then walked into the hot water tank (water temperature: $42^{\circ} \mathrm{C}$ ) and sat into it for $20 \mathrm{~min}$ (hot-HOI) while the same parameters were also measured. Finally, after coming out of the water tank, the participant rested for $120 \mathrm{~min}$ in sitting position in air (recovery period).

Venous blood samples were collected at $30 \mathrm{~min}$ (just before hot-HOI, pre-HOI), $50 \mathrm{~min}$ (immediately after HOI), $110 \mathrm{~min}$ (after $1 \mathrm{~h}$ of $\mathrm{HOI}$ ), and $170 \mathrm{~min}$ (after $2 \mathrm{~h}$ of HOI) from the start of the study. Blood samples were taken for measurement of serum IL-6, tumor necrosis factor-alpha (TNF- $\alpha$ ), high-sensitivity C-reactive protein (hsCRP), and counts of blood cells (CBC). The blood volume obtained at each sampling period was $5 \mathrm{~mL}$ ( $3 \mathrm{~mL}$ for serum IL-6, TNF- $\alpha$, hsCRP, and $2 \mathrm{~mL}$ for $\mathrm{CBC})$.

Total blood cell counts were determined using a cell counter. Hematocrit (Hct), hemoglobin (Hb), erythrocyte and leukocyte counts were measured by centrifugation. Other venous blood samples were collected into pre-chilled serum venipuncture tubes. The tubes were spun immediately at $3,500 \mathrm{rpm}$ for $10 \mathrm{~min}$ at $4{ }^{\circ} \mathrm{C}$, and serum was stored at $-80^{\circ} \mathrm{C}$ until analysis. IL-6 was measured by enzyme immunoassay (ELISA, R\&D Systems, Minneapolis, MN, USA) for IL-6 (R\&D Systems, Minneapolis, MN, USA) with assay sensitivity $0.039 \mathrm{pg} / \mathrm{mL}$ and intra- and inter-assay coefficients (average CV of different concentrations) of variability of 7.4 and $7.8 \%$, respectively. TNF- $\alpha$ was assayed using ELISA for TNF- $\alpha$ (R\&D Systems) with assay sensitivity $0.106 \mathrm{pg} / \mathrm{mL}$ and intra- and inter-assay coefficient of variability of 5.4 and $8.3 \%$, respectively. IL-6 and TNF- $\alpha$ immunoassays were performed in duplicates according to instructions provided by the manufacturer. Measurement of

Table 1. Characteristics of study participants

\begin{tabular}{lcc}
\hline \multicolumn{1}{c}{ Characteristics } & Elderly males $(\mathrm{n}=7)$ & Young males $(\mathrm{n}=8)$ \\
\hline Age $($ years $)$ & $68.4 \pm 1.4$ & $25.9 \pm 1.2^{*}$ \\
Height $(\mathrm{cm})$ & $164.4 \pm 1.2$ & $173.3 \pm 1.4^{*}$ \\
Weight $(\mathrm{kg})$ & $60.2 \pm 2.7$ & $70.1 \pm 4.2$ \\
Body mass index $\left(\mathrm{kg} / \mathrm{m}^{2}\right)$ & $22.3 \pm 1.2$ & $23.3 \pm 1.3$ \\
\hline
\end{tabular}

Data are mean \pm SD. ${ }^{*} \mathrm{p}<0.05$. 
hsCRP was out sourced to SRL Inc. (Tokyo, Japan). All measurements were performed by investigators unaware of the study protocol in Research Center of Sports Medicine and Balneology, Wakayama Medical University.

All results are expressed as mean $\pm \mathrm{SD}$. Values obtained at each study were compared by one-way analysis of variance followed by multiple comparisons at various time points. When the $F$ value was significant $(p<0.05)$, differences based on the time period and study condition were analyzed using the Tukey test. Differences between young and elderly persons were examined for statistical significance using the Student's t-test. P values $<0.5$ were considered significant.

\section{RESULTS}

The young individuals were taller than elderly persons $(\mathrm{p}<0.05)$ (Table 1). Other baseline measurements, including Tcore, serum IL-6, TNF- $\alpha$, hsCRP, and CBC were similar in the young and elderly individuals. HOI in $42{ }^{\circ} \mathrm{C}$ hot water for 20 min increased Tcore in both elderly and young individuals, although the magnitude of increase in Tcore was attenuated in elderly individuals compared with the young. The Tcore returned to pre-HOI level in young individuals at $2 \mathrm{~h}$ after HOI. On the other hand, $\mathrm{Hct}, \mathrm{Hb}$, and erythrocyte count in remained constant throughout the experiment in both groups of participants. Leukocyte count increased significantly after $2 \mathrm{~h}$ of HOI in the elderly (Table 2). Total water intake throughout the study was $508 \pm 42 \mathrm{~mL}$ in young persons and $0.8 \pm 0.3 \mathrm{~mL}$ in the elderly $(\mathrm{p}<0.05)$. Urine volume throughout the study was $84.4 \pm$ $42 \mathrm{~mL}$ in the young and $253 \pm 88.8 \mathrm{~mL}$ in the elderly. Serum IL-6 increased significantly in the young population after $1 \mathrm{~h}$ of hot-HOI and returned to the baseline level after $2 \mathrm{~h}$. In contrast, serum IL-6 level remained stable throughout the study in the elderly. Serum TNF- $\alpha$ and hsCRP did not change throughout the study in both groups (Table 3 ).

Table 2. Changes in hematocrit, hemoglobin, erythrocyte and leukocyte counts during hot water head-out water immersion

\begin{tabular}{lcccc}
\hline & Before immersion & Immediately after & \multicolumn{2}{c}{ After immersion } \\
\cline { 3 - 4 } & & & $1 \mathrm{~h}$ & $2 \mathrm{~h}$ \\
\hline Hematocrit $(\%)$ & & & & \\
$\quad$ Elderly men & $42.3 \pm 1.6$ & $42.3 \pm 1.9$ & $42.8 \pm 1.8$ & $38.4 \pm 4.4$ \\
$\quad \begin{array}{l}\text { Young men } \\
\text { Hemoglobin (g/dL) }\end{array}$ & $44.2 \pm 0.8$ & $45.6 \pm 0.9$ & $45.7 \pm 0.8$ & $44.4 \pm 1.3$ \\
$\quad \begin{array}{l}\text { Elderly men } \\
\text { Young men }\end{array}$ & $15.0 \pm 0.7$ & $15.1 \pm 0.7$ & $15.2 \pm 0.8$ & $15.1 \pm 0.7$ \\
Erythrocytes $\left(\times 10^{6} / \mu \mathrm{L}\right)$ & $15.0 \pm 0.3$ & $15.4 \pm 0.3$ & $15.4 \pm 0.3$ & $15.0 \pm 0.5$ \\
$\quad$ Elderly men & & & & \\
$\quad$ Young men & $4.7 \pm 0.2$ & $4.7 \pm 0.2$ & $4.8 \pm 0.2$ & $4.7 \pm 0.2$ \\
Leukocytes $\left(\times 10^{3} / \mu \mathrm{L}\right)$ & $4.9 \pm 0.1$ & $5.1 \pm 0.1$ & $5.1 \pm 0.1$ & $4.9 \pm 0.2$ \\
$\quad$ Elderly men & & & & \\
$\quad$ Young men & $5.0 \pm 0.5$ & $5.5 \pm 0.4$ & $6.0 \pm 0.4$ & $6.2 \pm 0.5^{*}$ \\
\hline
\end{tabular}

Data are mean \pm SD. ${ }^{*} \mathrm{p}<0.05$, compared with before immersion.

Table 3. Changes in core temperature, serum IL-6, serum TNF- $\alpha$ and hsCRP during hot water head-out water immersion

\begin{tabular}{lcccc}
\hline & Before immersion & Immediately after & \multicolumn{2}{c}{ After immersion } \\
\cline { 3 - 4 } & & & $1 \mathrm{~h}$ & $2 \mathrm{~h}$ \\
\hline Core temperature $\left({ }^{\circ} \mathrm{C}\right)$ & $36.8 \pm 0.4$ & $38.7 \pm 0.3^{*}$ & $37.6 \pm 0.3^{*}$ & $37.4 \pm 0.3^{*}$ \\
$\quad$ Elderly males & $36.9 \pm 0.4$ & $40.4 \pm 0.4^{* \dagger}$ & $37.4 \pm 0.3^{*}$ & $37.2 \pm 0.4$ \\
$\quad$ Young males & & & & \\
Serum IL-6 $(\mathrm{pg} / \mathrm{mL})$ & $1.6 \pm 1.1$ & $1.7 \pm 1.1$ & $1.8 \pm 0.9$ & $1.7 \pm 0.9$ \\
$\quad$ Elderly males & $0.9 \pm 0.7$ & $1.1 \pm 0.9$ & $1.6 \pm 1.1^{*}$ & $1.5 \pm 1.2$ \\
$\quad$ Young males & $1.0 \pm 0.6$ & & & $1.1 \pm 0.7$ \\
Serum TNF- $\alpha(\mathrm{pg} / \mathrm{mL})$ & $1.2 \pm 0.4$ & $1.0 \pm 0.5$ & $1.2 \pm 0.4$ & $1.3 \pm 0.6$ \\
$\quad$ Elderly males & & & & \\
$\quad$ Young males & $420.3 \pm 447.8$ & $424.7 \pm 464.8$ & $429.9 \pm 460.1$ & $408.1 \pm 426.1$ \\
hsCRP $($ ng/mL) & $336 \pm 369.9$ & $346.3 \pm 382.4$ & $352.4 \pm 375.9$ & $347 \pm 377.0$ \\
$\quad$ Elderly males & & &
\end{tabular}

Data are mean \pm SD. ${ }^{*} \mathrm{p}<0.05$, compared with before immersion. $\dagger \mathrm{p}<0.05$, Elderly vs. Young. 


\section{DISCUSSION}

The major findings of the present study were the followings: 1) 20-min hot water immersion attenuated the increase in Tcore in elderly individuals, 2) Although leukocyte count increased in the elderly, serum levels of TNF- $\alpha$ and hsCRP remained stable through the study in both groups, and 3) serum IL-6 increased significantly in young individuals after $1 \mathrm{~h}$ of hot-HOI, but not in the elderly. There has been no clear report on the effects of serum IL-6 associated with Hot-HOI. However, in this study, since IL-6 increased transiently during hot water immersion like exercise, it is considered that IL-6 has the same effect as IL-6 increased during exercise.

Attenuation of the Tcore response to hot-HOI observed in the elderly suggests possible degeneration of the thermal regulation system in this population. Davy et al. suggested that total blood volume decreases with age in healthy men ${ }^{17)}$. The reduced of circulation blood volume by the aging may be related to attenuation for Tcore rise during the hot-HOI. Thus, the greater skin blood volume induced by sensitive and well-controlled blood re-distribution system in young individuals resulted in a much larger increase in Tcore in this group compared with the elderly persons.

Regarding increasing of leukocyte count in the elderly, previous studies reported that the increase in Tcore during exercise under hot environment was associated with significant leukocytosis ${ }^{18-20)}$. Boldt et al. ${ }^{21)}$ investigated the effects of 50-min immersion in hot water (gradual increase in water temperature with maximum set at $41^{\circ} \mathrm{C}$ ), until reaching a body core temperature of $39^{\circ} \mathrm{C}$. In their study, the leukocyte count increased after 45 -min of hyperthermic immersion ${ }^{21)}$. The present study found an increase in leukocyte count at $2 \mathrm{~h}$ after hot-HOI in elderly individuals, suggesting that prolonged heat stress correlates with increase in leukocyte count in elderly persons.

One of the main findings of the present study was the lack of significant increase in serum IL-6 during hot-HOI in elderly individuals. This finding may be explained by the following two factors. First, IL-6 is produced by type II muscle fibers and the relative amount of type II muscle fibers in men is known to diminish with aging ${ }^{22}$. In this regard, IL-6 protein is expressed predominately in type II muscle fibers with high glycogen content ${ }^{23}$. However, type II muscle fibers show selective atrophy with aging ${ }^{22}$, 24). It is conceivable that the relative amount of IL-6 produced by type II muscle fibers decrease in the elderly with aging. Second, our results showed attenuation of the magnitude of increase in Tcore during hot-HOI in elderly individuals. Milanović et al. and Walc et al. $\left.{ }^{8}, 13\right)$ investigated previously the effects of hyperthermia on IL-6 level in skeletal muscles. In the present study, Tcore did not increase in the elderly during hot-HOI, relative to young persons. The effect of 20-min hot-HOI on serum IL-6 in the elderly did not seem to replicate the same effect of exercise on IL-6. One limitation of the present study was that elderly persons could not be exposed to hot water until Tcore max of $40^{\circ} \mathrm{C}$ was attained.

In conclusion, the present study demonstrated that head out water immersion in hot water induced attenuated rise in Tcore and weaker IL-6 response in elderly persons, compared with younger participants. It is possible that the heat stress of $42^{\circ} \mathrm{C}$ for $20 \mathrm{~min}$ in this study was insufficient to elevate serum IL-6. Physical therapist should understand the age-related changes in IL-6 during hot water-HOI and it is necessary to consider further research combined with exercise to elevate serum IL-6 in elderly people by physical therapist in the future.

\section{Conflicts of interest}

There are no conflicts of interest.

\section{REFERENCES}

1) Pedersen BK: Muscles and their myokines. J Exp Biol, 2011, 214: 337-346. [Medline] [CrossRef]

2) Nieman DC, Zwetsloot KA, Meaney MP, et al.: Post-exercise skeletal muscle glycogen related to plasma cytokines and muscle IL-6 protein content, but not muscle cytokine mRNA expression. Front Nutr, 2015, 2: 27. [Medline] [CrossRef]

3) Cabral-Santos C, Castrillón CI, Miranda RA, et al.: Inflammatory cytokines and BDNF response to high-intensity intermittent exercise: Effect the exercise volume. Front Physiol, 2016, 7: 509. [Medline] [CrossRef]

4) Jung S, Ahn N, Kim S, et al.: The effect of ladder-climbing exercise on atrophy/hypertrophy-related myokine expression in middle-aged male Wistar rats. J Physiol Sci, 2015, 65: 515-521. [Medline] [CrossRef]

5) Fischer CP: Interleukin-6 in acute exercise and training: what is the biological relevance? Exerc Immunol Rev, 2006, 12: 6-33. [Medline]

6) Pedersen BK: Special feature for the Olympics: effects of exercise on the immune system: exercise and cytokines. Immunol Cell Biol, 2000,78 : 532-535. [Medline] [CrossRef]

7) Pedersen BK, Fischer CP: Beneficial health effects of exercise - the role of IL-6 as a myokine. Trends Pharmacol Sci, 2007, 28: 152-156. [Medline] [CrossRef]

8) Milanović Z, Pantelić S, Trajković N, et al.: Age-related decrease in physical activity and functional fitness among elderly men and women. Clin Interv Aging, 2013, 8: 549-556. [Medline] [CrossRef]

9) Welc SS, Phillips NA, Oca-Cossio J, et al.: Hyperthermia increases interleukin-6 in mouse skeletal muscle. Am J Physiol Cell Physiol, 2012, 303: C455-C466. [Medline] [CrossRef]

10) Wright HE, McLellan TM, Friesen BJ, et al.: Influence of circulating cytokines on prolactin during slow vs. fast exertional heat stress followed by active or passive recovery. J Appl Physiol 1985, 2012, 113: 574-583. [Medline] [CrossRef]

11) Wright-Beatty HE, Hardcastle SG, Boulay P, et al.: Increased air velocity during exercise in the heat leads to equal reductions in hydration shifts and interleu- 
kin-6 with age. Eur J Appl Physiol, 2014, 114: 2081-2092. [Medline] [CrossRef]

12) Sakurai Y, Umemoto Y, Kawasaki T, et al.: Head-out immersion in hot water does not increase serum CXCL1 in healthy men. Trends Immunother, 2017, 1 : 28-34. [CrossRef]

13) Welc SS, Judge AR, Clanton TL: Skeletal muscle interleukin-6 regulation in hyperthermia. Am J Physiol Cell Physiol, 2013, 305: C406-C413. [Medline] [CrossRef]

14) Febbraio MA, Pedersen BK: Contraction-induced myokine production and release: is skeletal muscle an endocrine organ? Exerc Sport Sci Rev, 2005, 33: 114-119. [Medline] [CrossRef]

15) Kenney WL, Hodgson JL: Heat tolerance, thermoregulation and ageing. Sports Med, 1987, 4: 446-456. [Medline] [CrossRef]

16) Toft AD, Jensen LB, Bruunsgaard H, et al.: Cytokine response to eccentric exercise in young and elderly humans. Am J Physiol Cell Physiol, 2002, 283: C289C295. [Medline] [CrossRef]

17) Davy KP, Seals DR: Total blood volume in healthy young and older men. J Appl Physiol 1985, 1994, 76: 2059-2062. [Medline] [CrossRef]

18) Severs Y, Brenner I, Shek PN, et al.: Effects of heat and intermittent exercise on leukocyte and sub-population cell counts. Eur J Appl Physiol Occup Physiol, 1996, 74: 234-245. [Medline] [CrossRef]

19) Rhind SG, Gannon GA, Shek PN, et al.: Contribution of exertional hyperthermia to sympathoadrenal-mediated lymphocyte subset redistribution. J Appl Physiol 1985, 1999, 87: 1178-1185. [Medline] [CrossRef]

20) McFarlin BK, Mitchell JB: Exercise in hot and cold environments: differential effects on leukocyte number and NK cell activity. Aviat Space Environ Med, 2003, 74: 1231-1236. [Medline]

21) Boldt LH, Fraszl W, Röcker L, et al.: Changes in the haemostatic system after thermoneutral and hyperthermic water immersion. Eur J Appl Physiol, 2008, 102: 547-554. [Medline] [CrossRef]

22) Lexell J, Taylor CC, Sjöström M: What is the cause of the ageing atrophy? Total number, size and proportion of different fiber types studied in whole vastus lateralis muscle from 15- to 83-year-old men. J Neurol Sci, 1988, 84: 275-294. [Medline] [CrossRef]

23) Hiscock N, Chan MH, Bisucci T, et al.: Skeletal myocytes are a source of interleukin- 6 mRNA expression and protein release during contraction: evidence of fiber type specificity. FASEB J, 2004, 18: 992-994. [Medline] [CrossRef]

24) Tsuboi H, Nishimura Y, Sakata T, et al.: Age-related sex differences in erector spinae muscle endurance using surface electromyographic power spectral analysis in healthy humans. Spine J, 2013, 13: 1928-1933. [Medline] [CrossRef] 